\title{
An Evaluation of Climate Change Indigenous Coping and Adaptation Strategies for Sustainable Agro-Pastoral Based Livelihoods in Baringo County, Kenya
}

\author{
Edward W. Kimani ${ }^{1}$, George M. Ogendi ${ }^{2}$, Paul M. Makenzi ${ }^{2}$ \\ ${ }^{1}$ Agricultural Sector Development Support Programme (ASDSP), Samburu County, Kenya \\ ${ }^{2}$ Department of Environmental Science, Egerton University, Kenya
}

\begin{abstract}
It is now widely recognized that climate change is real. The frequency and severity of droughts, floods and unpredictable seasons in the recent past is a clear manifestation of the climate change. It is expected that these climatic events have negative implications on the indigenous coping and adaptation strategies of the communities residing where the events occur. This study was therefore carried out to establish whether any indigenous coping and adaptation strategies existed with the agro-pastoral communities in Baringo County, Kenya, and evaluate how they have coped and adapted to climate change using the indigenous knowledge. A social survey approach was adopted in the conduct of the study. Data was collected from 377 agro-pastoralists from 15 locations. Each of this location was used as a cluster. The sample was proportionately apportioned to each cluster, and simple random sampling procedure was adopted within the cluster. Data collection was done using questionnaires, focus group discussions, key informant interviews, observation schedules and secondary data review.

On analysis of the data, the study revealed existence and use of various indigenous coping and adaptation strategies. Among the strategies were, livestock relocation to wet or dry season grazing areas depending on the climatic event, diversification of both livestock and crops; herd adjustments through sale or herd splitting; use of local crops seeds; specialized food storage methods and controlled food rations during food insecure periods. From this revelation, it was concluded that there exits great wealth of indigenous knowledge with the local communities on adaptation to climate change. It was recommended that this indigenous knowledge should be used in complementarity with scientific knowledge while formulating socially acceptable and sustainable interventions.
\end{abstract}

Key Words: Climatic events, Drought, Floods, Resilience, Variability, Vulnerability

\section{Introduction}

The Intergovernmental Panel on Climate Change (IPCC) Fourth Assessment Report of 2007 gives convincing evidence that climate change is real and it is happening now; that it will become worse, and that the poorest in developing countries and most vulnerable people will be the worst affected (IPCC, 2007). Africa is one of the most vulnerable continents to climate change which is manifested in the short term by climate variability a situation aggravated by the interaction of multiple stresses in the form of weather uncertainties (unpredictable seasons), persistent climatic abnormalities (drought and floods), rampant environmental degradation and eminent food insecurity occurring at various levels, and low adaptive capacity to the impacts of these climatic related events (Boko et al., 2007). The IPCC (2007) further reports that communities residing in arid and semi-arid lands (ASALs), and whose livelihoods are highly dependent on natural resources are among the most vulnerable to climate change. Baringo County is one of such areas.

Indigenous peoples, however, are not mere victims of climate change. These local communities, through their indigenous knowledge systems, have developed and implemented coping and adaptation strategies that have enabled them reduce their vulnerability to past climate variability and change (Nyong, Adesina and Elasha, 2007; Worden, Western and Waruingi, 2009; Raygorodetsky, 2011). The ensuing community-based and collectively-held knowledge may offer valuable insights, which may complement scientific data with chronological and landscape-specific precision and detail that is critical for verifying climate models and evaluating climate change scenarios developed by scientists at much broader spatial and temporal scale. Moreover, indigenous knowledge may provide a crucial foundation for community-based adaptation and mitigation actions that sustain resilience of social-ecological systems at the interconnected local, regional and global scales (Raygorodetsky, 2011; Nakashima et al., 2012). Despite this, studies carried in Kenya and the Southern Sudan has revealed that dependency on traditional agro-pastoral based livelihood options alone is becoming increasingly untenable (Ouma et al., 2011). This notwithstanding, the ASALs of Kenya have been inhabited since time immemorial. This implies that the local communities' coping strategies have been able to make them survive through the climatic events impacts. However Yazan et al. (2012) found that the current 
livelihoods and resource use patterns in the dry lands are unsustainable and can no longer maintain the living standard of the inhabitants. Finding ways to improve livelihoods, food and nutrition security of households and alleviate poverty in the dry lands has thus become a key policy issue (Nyariki, Wiggins and Imungi, 2002). Strategies to reduce the vulnerability of people directly dependent upon the primary resources of the ASALs and to improve the productivity of those resources must be sought urgently (Ngugi and Nyariki, 2005).

This makes the need for diversification into and adoption of scientific technologies more and more urgent. However, out of tried scientific interventions, there has been also a growing awareness that scientific knowledge alone is inadequate for solving the climate change crisis (Finucane, 2009). A complementary mix of both indigenous knowledge and scientific interventions could therefore be a welcome option.

\section{Statement ofthe Problem}

Climate change is a reality. It has happened, it is happening, and it will continue to happen. In its wake it is affecting livelihood systems. However, human societies all across the globe have developed rich sets of experiences and explanations relating to the environments they live in. This indigenous knowledge guide them in their innumerable interactions with the natural environmental conditions. Through research findings, scientific knowledge has as well been generated. Despite the existence of the two types of knowledge, (indigenous and science), predictions are that climate change will increasingly continue to negatively impact on people world over especially those living in the ASALs of Africa. The design and implementation of any climate change policy, with a high potential of reducing the impacts occasioned by climate change hazards, especially drought and floods, at the local level, requires adequate knowledge about the perception, the existing knowledge the population has about the risks they are exposed to, the adaptation practices adopted, the existing capacity to adapt and the perceived barriers to adaptation. To address these issues and concerns there is need for a comprehensive assessment of the agro-pastoralists perception and adaptation to climate level at local level. The generated information could lead to complementary use of both indigenous and scientific knowledge in the policy and interventions formulation process. While scientific knowledge and its contribution to climate change adaptation are well documented, for the most part indigenous knowledge on coping and adaptation strategies remains in oral form. Existence of such indigenous knowledge and its contribution to the local communities' coping and adaptive capacity need to be established and documented.

\section{Objective}

The objective of this study was therefore to assess the indigenous agro-pastoral based livelihoods coping andadaptation strategies to the impacts of climate change by the communities of Baringo County, Kenya.

\section{Literature Review}

Indigenous knowledge on climatic change is vital in addressing food insecurity in ASALs. The World Bank underscores the crucial role that the knowledge capital of a nation plays in sustainable socioeconomic development and environmental sustainability. The World Bank (2012) says that the basic component of any country's knowledge system is its indigenous knowledge, which encompasses the skills, experiences and insights of people, applied to maintain or improve their livelihood. While this importance of indigenous knowledge has thus been realized in the design and implementation of sustainable development projects, little has been done to incorporate this into formal climate change mitigation and adaptation strategies (Nyong et al., 2007).

Further, although climate change impacts cover wide areas, regional differences may occur regarding the distribution of the climate change impacts and therefore there is a need to carry out place-specific analyses of adaptation to climate change in the present-day world (Elasha et al., 2006). This is because place-based research agenda is important for several reasons. First climate change effects and susceptibilities to them will most likely be regionally and locally uneven. Second, a growing understanding that people are good natural observers of their local environment has led to an appreciation of their knowledge, which is situated in cultural and ecological contexts and how it can provide important models and unique understandings of climate change.

\section{Climate change adaptation strategies in the Sahel}

The Sahel is the eco-climatic and biogeographic zone of transition, in Africa, between the Sahara desert to the north and the Sudanian Savannah to the south covering an area of approximately 3,053,200 $\mathrm{km}^{2}$ (Nyong et al., 2007). The belt extends roughly between $10.8^{\circ}$ and $20.8^{\circ} \mathrm{N}$. The region is characterized by severe and frequent droughts with records dating back into centuries even as far back as 1680s (Benson and Clay, 1998; Brooks, 1999; Hulme et al., 2001). The magnitude and intensity of these droughts have been on the increase over the last 100 years, with devastating consequences (Hulme et al., 2001). The local populations in this region, through their indigenous knowledge systems, have developed and implemented extensive mitigation and adaptation strategies that have enabled them reduce their vulnerability to past climate variability and change. 
This indigenous knowledge is however rarely taken into consideration in the design and implementation of modern mitigation and adaptation strategies (Hulme et al., 2001). This has led often to overlooking the potential in local experiences and practices. Hulme et al. (2001) illustrated this through the following experience from an Ethiopian food security program. Higher yielding sorghum varieties were introduced in Ethiopia to increase food security and income for farmers and rural communities. When weather and other conditions were favourable, the modern varieties proved a success. However, in some areas complete crop failures were observed, whereas local varieties, with a higher variance of traits, were less susceptible to the frequent droughts (World Bank, 2013).

IIRR et al. (2004) andNyong et al. (2007) give a list of indigenous adaptation strategies by the Sahelian communities, with a lot of emphasis on Ethiopia, both in the areas of crop and livestock production. For livestock production, adaptation strategies that are applied among the pastoralists include the use of emergency fodder in times of droughts, multi-species composition of herds to survive climate extremes, and culling of weak livestock for food during periods of drought. During drought periods, pastoralists and agro-pastoralists change from cattle to sheep and goat husbandry as the feed requirements of the later is less than the former. Pastoralists' nomadic mobility reduces the pressure on low carrying capacity grazing areas through the circular movement from the dry Northern areas to the wetter Southern areas of the Sahel. This system of seasonal movement represents a local type of traditional ranching management system of range resources. Though these studies endeavour to bring out adaptation strategies used by pastoral and agro-pastoral communities, they nevertheless cover a very wide area. More localized studies focussing on specific pastoral or agro-pastoral communities are likely to bring out differences in adaptations which on a wider scale may appear similar but are different in content and approach.

\section{Climate change adaptation strategies in Kenya}

The National Livestock Policy appreciates that over $80 \%$ of Kenya's land mass is in the ASALs, and that livestock is the main activity in these areas (GoK, 2008). The policy outlines the importance of the livestock sub-sector from which the importance of the ASALs is implied. Over $60 \%$ of all livestock in Kenya is found in the ASALs where it employs about $90 \%$ of the local population. The livestock sub-sector accounts for about $10 \%$ of the entire GDP and about $42 \%$ of the agricultural GDP. It also supplies the domestic requirements of meat, milk and dairy products, and other livestock products while accounting for about $30 \%$ of the total marketed agricultural products. The sub-sector earns the country substantial foreign exchange through export of live animals, hides and skins, dairy products, and some processed pork products. It also employs about 50 percent of the country's agricultural sector labour-force. This importance notwithstanding, presently, almost 57 percent of Kenya's population lives in poverty, largely attributable to reliance on climate-sensitive economic activities including rain fed "subsistence" or "smallholder" agriculture (Bryan et al. 2010; Ojwanget al., 2010; Ouma et al., 2011).

This state of poverty may imply that the environmental conditions and the adaptive strategies that the resident communities used to apply have become overwhelmed and thus their adaptive capacity has lowered. This assumption may be support by the changes in livelihoods systems from pastoralism to agro-pastoralism as reflected in most County Integrated Development Plans (CIDPs) from the ASAL counties including Baringo (GoK, 2013). The changes in livelihood systems are expected to have some implications on the traditional coping mechanisms. These implications need to be established in light of climate change mainly expressed through extreme climatic events of drought and floods. Some climatic extremes in Kenya are as tabulated in Table 1 as adapted from Ngaira (2006).

Although widespread, the effects of most of these events were felt most keenly by pastoralists in the districts of Garissa, Wajir, Mandera, Tana River, Moyale, Marsabit, Isiolo, Turkana, Samburu, Baringo, Laikipia, Koibatek, Kajiado and Narok; that is, the ASAL Districts of Kenya (Aklilu and Wekesa, 2002).

Table 1: Notable Regional Climate Anomalies in Kenya

\begin{tabular}{|l|l|}
\hline Year & Event \\
\hline 1961 & $\begin{array}{l}\text { Extremely high equatorial rainfall in East Africa which led to East African lakes rising in levels to above all twentieth } \\
\text { century record }\end{array}$ \\
\hline $1968-1973$ & $\begin{array}{l}\text { Severe phase of drought (Sahelian drought) in Ethiopia and the Sahel region which caused severe famines, animal } \\
\text { loss, desertification and reduced the size of Lake Chad. }\end{array}$ \\
\hline 1977 & Highest rainfall ever recorded in Kenya which caused severe gulley erosion, Lake level rise in semi - arid regions. \\
\hline 1984 & Severe droughts in Kenya led to the introduction of "food queues" in supermarkets. \\
\hline $1991-1993$ & $\begin{array}{l}\text { Severe droughts in most arid areas in Kenya led to the introduction of "food for work" programmes, and reduced } \\
\text { surface areas of the lakes in the region. }\end{array}$ \\
\hline $1996-1998$ & $\begin{array}{l}\text { Kenya experienced the worst floods in 36 years caused by El-nino which increased surface area of Lakes in the rift } \\
\text { valley. }\end{array}$ \\
\hline $1999-2001$ & $\begin{array}{l}\text { Affected not only the perennially drought-prone arid districts of northern Kenya, but also the marginal agricultural } \\
\text { areas of Eastern, Coast and Rift Valley provinces, as well as high-rainfall areas such as the Central Province. }\end{array}$ \\
\hline 2009 & A drought year in Kenya \\
\hline
\end{tabular}


Source: Adapted with expansion from Ngaira, (2006).

\section{Climate change adaptation strategies in Baringo County}

Studies with some bearing on indigenous adaptive mechanisms have been carried out within the Baringo County. For example, the Baringo Pilot Semi-Arid Area Project (BPSAAP) was carried out around Lake Baringo in the Great Rift Valley. However the study covered only one-third of Baringo District (currently Baringo County) and only concerned itself with herd dynamics over a period of three (3) years (Homewood and Lewis, 1987). A study by Makenzi (2004) investigated indigenous knowledge in natural resources management but lacked linkage to climate change.

A regional survey by Homewood and Lewis(1987) on livestock found net reductions of about 50\% during the first 9 months of drought in all zones and for all species herds, but stock losses varied with species, locality, herd management and stage of drought. Stock redistribution complicated estimates of mortality based on regional data but could be analysed through intensive herd data. Cattle herds were moved considerable distances to find better pasture, while small stock mostly remained at the homestead. Highest stock loss percentages occurred in the zones of greatest production potential. Contrasting ecological zones showed superficially similar stock loss figures but had different underlying dynamics. Owner-managed cattle did better than cattle placed with hired herders. Stock redistribution and the cattle and small stock trade produced anomalous local increases in an overall pattern of stock loss. During the study there was an initial phase of cattle movement, a subsequent phase of high mortality but continued high fertility, and a final phase of much lower mortality (despite continued severe drought), with no calving in cattle. These patterns differ from those commonly assumed in drought simulation models.

\section{Importance of indigenous knowledge}

In the emerging global knowledge economy a country's ability to build and mobilize knowledge capital, is equally essential for sustainable development as the availability of physical and financial capital (World Bank, 2012). The basic component of any country's knowledge system is its indigenous knowledge. It encompasses the skills, experiences and insights of people, applied to maintain or improve their livelihood.

Significant contributions to global knowledge have originated from indigenous people, with their intimate understanding of their environments. Indigenous knowledge is developed and adapted continuously to gradually changing environments and passed down from generation to generation and closely interwoven with people's cultural values. Indigenous knowledge is also the social capital of the poor, their main asset to invest in the struggle for survival, to produce food, to provide for shelter or to achieve control of their own lives.

Today, many indigenous knowledge systems are at risk of becoming extinct because of rapidly changing natural environments and fast pacing economic, political, and cultural changes on a global scale. Practices vanish, as they become inappropriate for new challenges or because they adapt too slowly (Nyong et al., 2007). However, many practices disappear only because of the intrusion of foreign technologies or development concepts that promise short-term gains or solutions to problems without being capable of sustaining them. The tragedy of the impending disappearance of indigenous knowledge is most obvious to those who have developed it and make a living through it. But the implication for others can be detrimental as well, when skills, technologies, artefacts, problem solving strategies and expertise are lost.

\section{Indigenous people and indigenous knowledge}

People inhabiting a region for a long time may be referred to as indigenous to the area. While people indigenous in ASALs are acknowledged to be among the most vulnerable communities due to a combination of political, economic and social factors as well as erratic rainfall (Trench et al., 2007), it is these people who have an extensive knowledge about adaptation to climate change and who have successfully managed and lived on ASAL ecosystems over centuries. ASALs are characterized not so much by a shortage of water, but by its erratic availability and a variable climate. Consequently, Trench et al. (2007), argue for instance,that pastoralists will be best equipped to adapt to climate change given their traditional knowledge and management systems. However, most ASAL areas are often characterized by remoteness, poor infrastructure, limited basic services and a poor government presence. In addition, land tenure systems and inadequate policies compounded with climate change impacts have further marginalized ASALs people.Despite this, people resident in ASALs have had to adapt constantly to a highly variable climate through their vast adaptive knowledge. However over time and space, it is apparent that the ASAL communities' adaptive capacities have been severely undermined and they have become in many cases more vulnerable than other communities. If adaptation and development strategies embrace the sustainable management of ASALs and promote the adaptive capacity of indigenous peoples and local communities, there is a potential that ASAL livelihood systems, such as agro-pastoralism, may in fact provide food resources where climate change lead to lower reliability of marginal farming. 


\section{Study area}

\section{Study Methodology}

The study was carried out within the Baringo County. Baringo is one of the 47 Counties in Kenya (GoK, 2010). The County lies between Latitudes $0^{\circ} 12^{\prime}$ and $1^{\circ} 36^{\prime} \mathrm{N}$ and Longitudes $35^{\circ} 36^{\prime}$ and $36^{\circ} 30^{\prime} \mathrm{E}$. It borders Turkana County to the North, Samburu and Laikipia Counties to the East; Nakuru to the South; and Keiyo, Marakwet and West Pokot Counties to the West.The study will however concentrate on the Eastern semi-arid areas of Marigat Sub-County, (Marigat and Mochongoi Divisions), described in this study as Lower Midland Zone (LM) and Inner Lowland Zone (IL)(shown shaded in figure 4). The sub-county County covers $1423 \mathrm{Km}^{2}$ of which about $139.5 \mathrm{Km}^{2}$ is covered by water surface. Lake Baringo covers an area of $130 \mathrm{Km}^{2}$ and Lake Bogoria $9.5 \mathrm{Km}^{2}$. The Sub-County lies between Latitudes $0^{\circ} 12^{\prime}$ and $0^{\circ} 38^{\prime} \mathrm{N}$ and Longitudes $35^{\circ} 50^{\prime}$ and $36^{\circ} 18^{\prime} \mathrm{E}(\mathrm{GoK}, 2013)$.

\section{Topography and climate}

The major topographical features in the Sub-County are river valleys and plains, the Tugen Hills, the floor of the Rift Valley and the Northern plateau. In the Eastern part of the Sub-County near Lakes Bogoria and Baringo is the Loboi plain covered mainly by the lacustrine salt-impregnated silt deposits.

The Tugen Hills in the South Western part of the County form a conspicuous topographical feature. The altitude varies from $1000 \mathrm{~m}$ to $2600 \mathrm{~m}$ above sea level. The Hills occur in a North-South direction and mainly consist of volcanic rocks. The Hills have steep slopes dissected by gullies. On the Eastern and Western parts of the Hills there are the escarpments and the rivers flowing down these Hills pass through very deep gorges.

The County has different agro-ecological zones necessitating different agricultural activities (GoK, 2013).The troughs of the Rift which have a North-South alignment are occupied by the Lakes Bogoria and Baringo. Most of the Sub-County is either too steep (Tugen Hills) or too plain (Eastern parts around Lake Baringo). The lowlands or plains are very dry.

\section{Rainfall}

Baringo County is one of the arid and semi-arid Counties in the country with much of the County receiving low to average annual rainfall. However, within the County there are some high potential areas neighbouring the Hills and the highlands that receive high rainfall. The County experiences two seasons of rainfall; the long rains start from the end of March to the beginning of July, and the short rains from the end of September to November. The rainfall is about $50 \%$ reliable. It varies from $1000-1500 \mathrm{~mm}$ in the highlands to $500-600 \mathrm{~mm}$ in the lowlands in the North-Eastern part of the County. The rainfall distribution pattern means that major cropping activities are concentrated in the highland areas which have adequate rainfall. These areas are found in Kabartonjo, Tenges, Sacho and Kabarnet Divisions. The major farming activities include dairying, growing of maize, groundnuts, cotton and coffee. The remainder of the County is mainly rangelands with the rearing of goats, sheep, cattle, camels and bee-keeping forming the major livestock activities (GoK, 2013).

\section{Temperatures}

The mean annual maximum temperature in the County lies between $25^{\circ} \mathrm{C}$ and $30^{\circ} \mathrm{C}$ in the Southern part. In the Northern part, the mean annual maximum temperature is about $30^{\circ} \mathrm{C}$ and occasionally rises to over $35^{\circ} \mathrm{C}$. The hottest months are from January to March. The mean annual minimum temperature varies from $16^{\circ}$ to $18^{\circ} \mathrm{C}$ but can drop to as low as $10^{\circ} \mathrm{C}$ in the Tugen Hills. The main factor influencing the variation in temperature is the altitude. In the highland of the Tugen Hills with an altitude of $2600 \mathrm{~m}$, the temperatures are much lower than in the lowlands of Marigat, Kerio Valley and Nginyang where the altitude ranges between $762 \mathrm{~m}$ and $1000 \mathrm{~m}$ above sea level (GoK, 2013). 


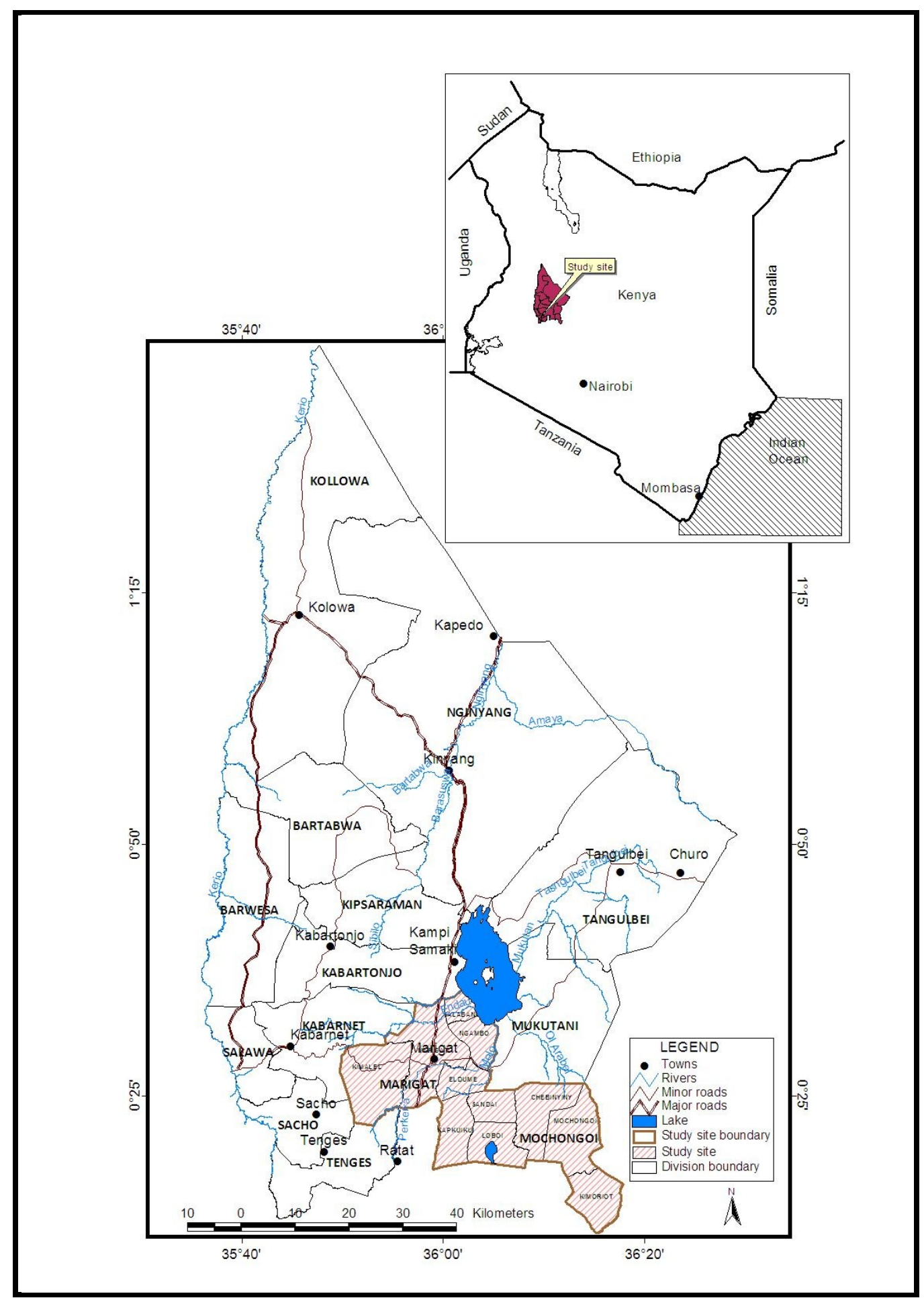

Figure 1: Map of the study area

The study area is shown checked on the map.

\section{Research design}

This study adopted a cross sectional survey design. Using this design, a sample of the population was selected, and from these individuals, data was collected to help answer the research questions. This design was selected for the advantage that the information about independent and dependent variables that was gathered represents what goes on at only one point in time (Olsen and George, 2004). Data collection tools included secondary data review, Focused Group Discussions (FGDs), Participatory Rural Appraisals (PRAs), questionnaires, key informant interviews and personal observations (Figures 2). 


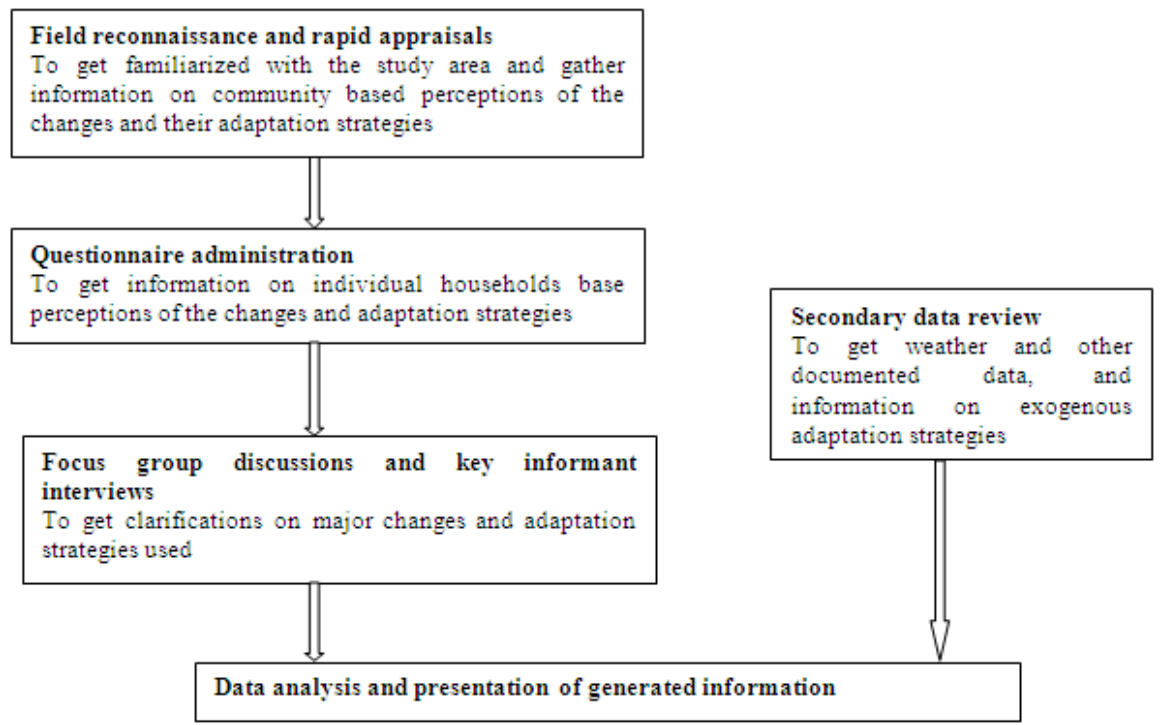

Figure 3: Study design framework

\section{Results and Discussion}

The importance of various livelihood sources to the community was investigated. The results are as discussed below.

\section{Livestock-based livelihoods}

In areas such as the drought-prone regions of Kenya, indigenous communities are engaged in both short- and long-term management of acute and chronic threats to household food security. In the short term, these cycles directly threaten lives by attacking the basis for their livelihoods (livestock and crops) (Aklilu and Wekesa, 2002). Over time, the accumulated shocks these communities face may mean that their resilience decreases. To establish therefore how the communities coped, their livestock-based coping strategies were investigated.

\section{A. Livestock species}

To begin with, the indigenous species of livestock kept was investigated. It was disclosed that the indigenous breeds of livestock in the area were predominantly red Maasai and black head Persian for sheep; the zebu for cattle; and the small east African goat for goats.

\section{B. Importance of livestock based livelihoods}

The importance of livestock to the community was assessed. Table 20 shows that $95.5 \%$ of the respondents considered livestock as an important to most important source of their livelihoods. This may be explained that the communities have strong affinity for livestock as a livelihood source. This could be related to Tolera and Abebe (2007) about the Borana, another ASAL community, that they have a very strong attachment to cattle rearing.

Table 2: Importance of Livestock in Livelihoods

\begin{tabular}{llrrr}
\hline Importance of livestock in livelihoods & Frequency & Valid Percent & Cumulative Percent \\
\hline Valid & Most Important & 122 & 34.3 & 34.3 \\
& More Important & 165 & 46.3 & 80.6 \\
& Important & 53 & 14.9 & 95.5 \\
& Less Important & 14 & 3.9 & 99.4 \\
& Least Important & 2 & .6 & 100.0 \\
\cline { 2 - 5 } & Total & $\mathbf{3 5 6}$ & $\mathbf{1 0 0 . 0}$ & $\mathbf{1 0 0 . 0}$ \\
\hline
\end{tabular}

$\mathbf{N}=356$

Source: Author's survey

\section{Herding}

On analysing who carries out the herding activity, the results revealed that it was mainly done by the males with the boys taking the higher proportion of $38 \%$. 


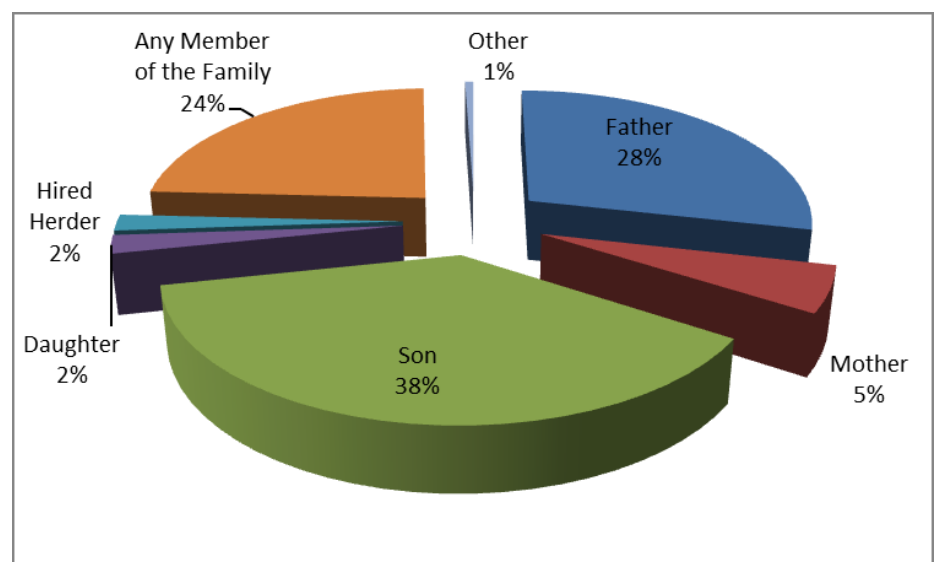

Figure 4: Herders and agro-pastoral production systems.

Source: Author's Survey

Herding is a very important activity in pastoral and agro-pastoral production systems (Steinfeld and Maki-Hokkonen, 1997). The results could be explained that culturally ruminant livestock is considered as a reservoir of value. Secondly pastoral grazing involves movement take involve long distances which is incompatible with the reproductive roles of women. Further, in some instances insecurity issues dictate that young strong men take care of the livestock.

\section{Crop-based livelihoods}

Table 3 shows that $95.8 \%$ of the respondents considered crops as an important to most important source of their livelihoods. Note that 17 respondents failed to respond. This may imply that they were not involved in crop production.

Table 3: Importance of Crop-based Livelihoods

\begin{tabular}{llrrrr}
\hline Importance of crop-based livelihoods & Frequency & Percent & Valid Percent & Cumulative Percent \\
\hline Valid & Most Important & 193 & 51.2 & 53.6 & 53.6 \\
& More Important & 113 & 30.0 & 31.4 & 85.0 \\
& Important & 39 & 10.3 & 10.8 & 95.8 \\
& Less Important & 14 & 3.7 & 3.9 & 99.7 \\
& Least Important & 1 & .3 & .3 & 100.0 \\
\cline { 2 - 5 } & Total & $\mathbf{3 6 0}$ & $\mathbf{9 5 . 5}$ & $\mathbf{1 0 0 . 0}$ & \\
\cline { 2 - 5 } Missing & System & 17 & 4.5 & \\
\hline \multicolumn{1}{l}{ Total } & $\mathbf{3 7 7}$ & $\mathbf{1 0 0 . 0}$ & \\
\hline
\end{tabular}

$\mathbf{N}=3 \overline{77}$

Source: Author's Survey

\section{Wage-based Livelihoods}

Table 4 shows that $68.6 \%$ of the respondents considered wage employment as an important to most important source of their livelihoods. Note that 116 respondents failed to respond. This number may explain the national scenario of unemployment in the formal job market.

Table 4: Importance of Wage-based Livelihoods

\begin{tabular}{llrrrr}
\hline Importance of Wage-based Livelihoods & Frequency & Percent & Valid Percent & Cumulative Percent \\
\hline Valid & Most Important & 33 & 8.8 & 12.6 & 12.6 \\
& More Important & 37 & 9.8 & 14.2 & 26.8 \\
& Important & 109 & 28.9 & 41.8 & 68.6 \\
& Less Important & 53 & 14.1 & 20.3 & 88.9 \\
& Least Important & 29 & 7.7 & 11.1 & 100.0 \\
\cline { 2 - 5 } & Total & $\mathbf{2 6 1}$ & $\mathbf{6 9 . 2}$ & $\mathbf{1 0 0 . 0}$ & \\
\cline { 2 - 6 } Missing & System & 116 & 30.8 & \\
\hline Total & & $\mathbf{3 7 7}$ & $\mathbf{1 0 0 . 0}$ &
\end{tabular}

$\mathbf{N}=377$

Source: Author's Survey 


\section{Business-based livelihoods}

Table 5 shows that $33.3 \%$ of the one hundred and ninety eight respondents considered business as an important to most important source of their livelihoods. Note that 179 respondents, comprising $47.5 \%$ of the three hundred and seventy seven respondents to whom the question was posed failed to respond. The high number of non-respondents may be explained as those who don't earn their living through formal businesses.

Table 5: Importance of Business-based Livelihoods

\begin{tabular}{|c|c|c|c|c|c|}
\hline \multicolumn{2}{|c|}{ Importance of Business-based livelihoods } & \multirow{2}{*}{$\begin{array}{r}\text { Frequency } \\
12\end{array}$} & \multirow{2}{*}{$\begin{array}{r}\text { Percent } \\
3.2\end{array}$} & \multirow{2}{*}{$\begin{array}{r}\text { Valid Percent } \\
6.1\end{array}$} & \multirow{2}{*}{$\begin{array}{r}\text { Cumulative Percent } \\
6.1\end{array}$} \\
\hline Valid & Most Important & & & & \\
\hline & More Important & 7 & 1.9 & 3.5 & 9.6 \\
\hline & Important & 47 & 12.5 & 23.7 & 33.3 \\
\hline & Less Important & 76 & 20.2 & 38.4 & 71.7 \\
\hline & Least Important & 56 & 14.9 & 28.3 & 100.0 \\
\hline & Total & 198 & 52.5 & 100.0 & \\
\hline Missing & System & 179 & 47.5 & & \\
\hline Total & & 377 & 100.0 & & \\
\hline
\end{tabular}

$\mathbf{N}=377$

Source: Author's Survey

The results of the assessment of the four major sources of livelihoods in the study area revealed that crops and livestock were the two key sources of livelihoods for the community.

\section{Implications of the Climatic Changes on Livelihoods}

\section{Climate change impacts on livestock production}

On investigation of which climate change impacts would have effects on livestock production, the results revealed that rainfall had significant impact on livestock production $(\chi 2=62.886, p=0.000)$ (Table 6). The perceived reduction of rainfall as discussed earlier was expected to have some implications on how the communities handled the aspect of livestock production. Rainfall contributes a major resource, water, which is a paramount factor for sustenance of life. Water allows pasture growth and is used for drinking.

According to the National Development Plan 2002-2008, Kenya is recognized as a water scarce country whereby the water demand exceeds renewable fresh-water sources; its potential annual freshwater are quite small, with surface water estimated at 19,590 million $\mathrm{m}^{3}$ and ground water at 619 million $\mathrm{m}^{3}$ (NEMA, 2009). Climate change is expected to have a substantial effect on water availability in the future. Already access to water has been reported to be on the decline since the 1970s (Olago, Opere and Barongo, 2009). According to Olago et al. (2009) Kenya had some $1500 \mathrm{~m}^{3}$ per person per year renewable fresh water in the early 1970 s but per capita availability now stands at $700 \mathrm{~m}^{3}$, and is projected to fall to $235 \mathrm{~m}^{3}$ per capita by the year 2025 if no interventions are put in place. Moreover, the available resources are unevenly distributed both geographically and seasonally. United Nations, (2006) reaffirms that water scarcity is increasing at an accelerated pace and affects between 1 and 2 billion people globally (UN, 2006).

According to Rowlinson (2008) climate change will have far-reaching consequences for livestock production, mainly arising from its impact on grassland and rangeland productivity. Heat distress suffered by animals will reduce the rate of animal feed intake and result in poor growth performance (Rowlinson, 2008). Lack of water and increased frequency of drought in certain areas, especially ASALs, will lead to a loss of resources. Consequently, as exemplified by events in many African countries, existing food insecurity and conflict over scarce resources such as pastures and water will be exacerbated.

Table 6: Impact of rainfall on livestock production

\begin{tabular}{|c|c|c|c|c|c|c|c|c|c|}
\hline & & \multicolumn{5}{|c|}{ Decreasing Rainfall } & \multirow[b]{2}{*}{ Total } & \multirow[b]{2}{*}{$\chi 2$} & \multirow[b]{2}{*}{$\mathbf{p}$} \\
\hline & & $\begin{array}{l}\text { Strongly } \\
\text { agree }\end{array}$ & $\begin{array}{l}\text { Somewhat } \\
\text { agree }\end{array}$ & $\begin{array}{l}\text { Don't } \\
\text { know }\end{array}$ & $\begin{array}{c}\text { Somewhat } \\
\text { disagree }\end{array}$ & $\begin{array}{l}\text { Strongly } \\
\text { disagree }\end{array}$ & & & \\
\hline \multirow{5}{*}{$\begin{array}{l}\text { Impact } \\
\text { Livestock }\end{array}$} & on Strongly agree & 46 & 32 & 3 & 8 & 12 & 101 & 62.886 & 0.000 \\
\hline & $\begin{array}{l}\text { Somewhat } \\
\text { agree }\end{array}$ & 24 & 48 & 3 & 16 & 13 & 104 & & \\
\hline & Don't know & 6 & 2 & 1 & 1 & 1 & 11 & & \\
\hline & $\begin{array}{l}\text { Somewhat } \\
\text { disagree }\end{array}$ & 6 & 18 & 3 & 27 & 8 & 62 & & \\
\hline & $\begin{array}{l}\text { Strongly } \\
\text { disagree }\end{array}$ & 36 & 25 & 6 & 12 & 13 & 92 & & \\
\hline
\end{tabular}


An Evaluation of Climate Change Indigenous Coping and Adaptation Strategies for.....

\begin{tabular}{|c|c|c|c|c|c|c|c|c|c|}
\hline & & \multicolumn{5}{|c|}{ Decreasing Rainfall } & \multirow[b]{2}{*}{ Total } & \multirow[b]{2}{*}{$x^{2}$} & \multirow[b]{2}{*}{ p } \\
\hline & & $\begin{array}{l}\text { Strongly } \\
\text { agree }\end{array}$ & $\begin{array}{l}\text { Somewhat } \\
\text { agree }\end{array}$ & $\begin{array}{l}\text { Don't } \\
\text { know }\end{array}$ & $\begin{array}{l}\text { Somewhat } \\
\text { disagree }\end{array}$ & $\begin{array}{l}\text { Strongly } \\
\text { disagree }\end{array}$ & & & \\
\hline \multirow{5}{*}{$\begin{array}{l}\text { Impact } \\
\text { Livestock }\end{array}$} & on Strongly agree & 46 & 32 & 3 & 8 & 12 & 101 & 62.886 & 0.000 \\
\hline & $\begin{array}{l}\text { Somewhat } \\
\text { agree }\end{array}$ & 24 & 48 & 3 & 16 & 13 & 104 & & \\
\hline & Don't know & 6 & 2 & 1 & 1 & 1 & 11 & & \\
\hline & $\begin{array}{l}\text { Somewhat } \\
\text { disagree }\end{array}$ & 6 & 18 & 3 & 27 & 8 & 62 & & \\
\hline & $\begin{array}{l}\text { Strongly } \\
\text { disagree }\end{array}$ & 36 & 25 & 6 & 12 & 13 & 92 & & \\
\hline Total & & 118 & 125 & 16 & 64 & 47 & 370 & & \\
\hline
\end{tabular}

Source: Author's Survey

\section{Animal and human health}

In the course of the study increase in formerly known and occurrence of emerging diseases affecting both livestock and human were revealed. Increase of cholera and malaria in human; East Coast Fever and Foot and Mouth diseases in livestock; and emergence of Rift valley Fever in livestock were mentioned as key diseases of concern. Treatment of such diseases was said to have overwhelmed the coping capacities of the local communities. This revelation concurred with Raleigh et al., (2008), that Vector-borne diseases could be affected by: the expansion of vector populations into cooler areas (in higher altitude areas: malaria and livestock tickborne diseases) or into more temperate zones (such as bluetongue disease in Northern Europe); and changes in rainfall pattern during wetter years, which could also lead to expanding vector populations and large-scale outbreaks of disease (e.g. Rift Valley fever virus in East Africa) (Raleigh et al., 2008). Temperature and humidity variations could have a significant effect on ecto- and endo-parasite infections. Some traits such as Trypanotolerance, an adaptive trait of certain West-African, taurine breeds of cattle to remain productive and gain weight after trypanosome infection, which has developed over the course of millennia in sub-humid zones of West Africa, could be lost (Naessens, 2006). This could lead to a greater risk of disease in the future. Changes in crop and livestock practices could produce effects on the distribution of mosquito and consequently the impact of malaria on human health. Similarly schistosomiasis and lymphatic filariasis could be exacerbated in irrigated systems (Figure 3). Heat-related mortality and morbidity could increase.

\begin{tabular}{ll}
\hline Diseases & Vector \\
\hline Malaria, filariasis, dengue fever, yellow fever, West Nile Fever & Mosquitoes \\
Leishmaniasis & Sand flies \\
Chagas' disease & Triatomines \\
Lyme disease, tick-borne encephalitis & Ixodes Ticks \\
African trypanosomiasis & Tsetse flies \\
Onchocerciasis & Black flies \\
\hline
\end{tabular}

Figure 5: Climate Change Enhanced Diseases

Source: Adapted from WHO, (2003)

\section{Climate change impacts on crop production}

As was the case with livestock, the effect of the change in rainfall on crop production was investigated. The results revealed that the rainfall had significant impact on crop production $\left(\chi^{2}=54.669, \mathrm{p}=0.000\right)$ (Table 7). The results on the implications of rainfall on both livestock and crop production were in agreement with those by Ojwanget al., (2010). In their study of the climate change impacts and concerns among smallholder farmers in the Laikipia and Narok districts, (also ASAL areas), they concluded that:

i. Abnormal onset of the rainy season results in severe consequences, where abrupt floods destroy infrastructure and hamper physical mobility, damage crop fields, increase disease epidemics, death to livestock, and severe impact on livelihoods;

ii. Increased frequency and severity of droughts has aggravated the aridity of the drylands, making it drier and adversely affecting ecosystems balance (biodiversity and habitats), livelihoods of communities who depend on livestock keeping, smallholder rain fed agriculture and overall food security.

iii. Prolonged droughts lead to famine, which adversely affect particularly the elderly, women and children, and often result in severe malnutrition, diseases and deaths.

iv. Droughts have led to rampant environmental degradation, resource use conflicts and desertification. 
Table 7: Impact of rainfall on Crop production

\begin{tabular}{|c|c|c|c|c|c|c|c|c|c|}
\hline & & \multicolumn{5}{|c|}{ Decreasing Rainfall } & \multirow[b]{2}{*}{ Total } & \multirow[b]{2}{*}{$\chi^{2}$} & \multirow[b]{2}{*}{$\mathbf{p}$} \\
\hline & & $\begin{array}{l}\text { Strongly } \\
\text { agree }\end{array}$ & $\begin{array}{l}\text { Somewhat } \\
\text { agree }\end{array}$ & $\begin{array}{l}\text { Don't } \\
\text { know }\end{array}$ & $\begin{array}{c}\text { Somewhat } \\
\text { disagree }\end{array}$ & $\begin{array}{l}\text { Strongly } \\
\text { disagree }\end{array}$ & & & \\
\hline \multirow{5}{*}{$\begin{array}{l}\text { Impact on crop } \\
\text { production }\end{array}$} & Strongly agree & 54 & 32 & 5 & 7 & 12 & 110 & 54.669 & 0.000 \\
\hline & Somewhat agree & 24 & 55 & 5 & 24 & 13 & 121 & & \\
\hline & Don't know & 7 & 2 & 1 & 2 & 1 & 13 & & \\
\hline & $\begin{array}{l}\text { Somewhat } \\
\text { disagree }\end{array}$ & 10 & 13 & 3 & 21 & 8 & 55 & & \\
\hline & Strongly disagree & 23 & 23 & 2 & 12 & 13 & 73 & & \\
\hline Total & & 118 & 125 & 16 & 66 & 47 & 372 & & \\
\hline
\end{tabular}

$\mathbf{N}=372$

Source: Author's Survey

\section{Indigenous crop-based coping strategies}

Agriculture in Kenya is important for rural livelihoods, food, and the national economy (earning $60 \%$ of foreign exchange and $24 \%$ of GDP) as well as providing employment for $80 \%$ of the population (GoK, 2011). Agriculture is generally the first economic sector to be affected by climate extremes through drought and floods. Droughts have an immediate impact on crop output by way of withering and drying off due to lack of soil moisture, while floods cause loss through water logging and loss of plant nutrients through leaching and erosion. Already the unpredictability of Kenya's year-to-year productivity causes substantial problems for poor subsistence farmers, as rain fed crops are lost during unusually dry or wet seasons (Mutimba et al., 2010).

A poorly performing agricultural sector puts the country's food security at risk. Kenya has in the recent past reported successive seasons of crop failure, increasing the country's food insecurity (Anderson, Gundel \& Vanni, 2010). The country's famine cycles have reduced from 20 years (1964-1984), to 12 years (1984-1996), to 2 years (2004-2006) and to yearly 2007/2008/2009, necessitating the Government's distribution of $528,341.77$ metric tonnes (MT) of assorted foodstuffs worth Ksh. 20 billion over the last five years to feed a population of between 3.5 million and 4.5 million people annually (Mutimba et al., 2010).

The climate change impacts that could affect agro-pastoral production in Baringo were expected to include drought, floods, heat stress and soil structure change. Owing to the very survival of the resident communities through such climatic events in the past, it was expected that they had indigenous coping strategies some of which could have grown into adaptation strategies. Cognisance of this important role played by indigenous coping and adaptation strategies triggered the need to investigate how the indigenous communities within the study area traditionally coped with what they perceived to be climate change and more so the associated shocks such as drought and floods. Several indigenous crop-based coping strategies were investigated and the findings are as tabulated in Table 8.

Table 8:Indigenous Crop Based Coping Strategies

\begin{tabular}{|c|c|c|c|c|c|}
\hline \multicolumn{2}{|l|}{ Coping Strategy } & \multirow{2}{*}{$\frac{\text { Frequency }}{211}$} & \multirow{2}{*}{$\frac{\text { Valid Percent }}{57.0}$} & \multirow{2}{*}{$\begin{array}{c}\text { Cumulative Percent } \\
57.0\end{array}$} & \multirow{2}{*}{$\frac{\mathbf{N}}{370}$} \\
\hline Crop diversification & Yes & & & & \\
\hline & No & 159 & 43.0 & 100.0 & \\
\hline \multirow[t]{2}{*}{ Mixed cropping } & Yes & 208 & 56.5 & 56.5 & 368 \\
\hline & No & 160 & 43.5 & 100.0 & \\
\hline \multirow[t]{2}{*}{ Increase area under crops } & Yes & 84 & 23.0 & 23.0 & 365 \\
\hline & No & 281 & 77.0 & 100.0 & \\
\hline \multirow[t]{2}{*}{ Water harvesting } & Yes & 107 & 29.5 & 29.5 & 363 \\
\hline & No & 256 & 70.5 & 100.0 & \\
\hline \multirow[t]{2}{*}{ Short season cropping } & Yes & 240 & 64.9 & 64.9 & 370 \\
\hline & No & 130 & 35.1 & 100.0 & \\
\hline \multirow[t]{2}{*}{ Crop Protection } & Yes & 108 & 29.8 & 29.8 & 362 \\
\hline & No & 254 & 70.2 & 100.0 & \\
\hline \multirow[t]{2}{*}{ Soil fertilization } & Yes & 199 & 55.0 & 55.0 & 362 \\
\hline & No & 163 & 45.0 & 100.0 & \\
\hline
\end{tabular}

Source: Author's Survey 


\section{A. Crop diversification}

Investigation was carried out in order to establish whether the indigenous community traditionally used diversification as a coping strategy. On analysing this item, results showed that $57 \%$ of the respondents practiced this coping strategy (Table 8). This may explain that the indigenous community had indigenous knowledge that a diversified portfolio of crop products would ensure that farmers do not suffer complete ruin when the weather is unpredictable. The respondents mentioned traditional maize varieties; finger millet; sorghum; local varieties of sweet potatoes; and cassava as the traditionally grown crops.

Crop diversification is intended to give a wider choice in the production of a variety of crops in a given area so as to expand production related activities on various crops and also to lessen risk related to climate change (Njeru, 2013). However even crops that are indigenous in one area or improved varieties of the same may not always prove to be suitable in other areas though the areas may appear to be ecologically the same. For exampleHulme et al. (2001) cites a case in Ethiopia where higher yielding sorghum varieties were introduced to increase food security and income for farmers and rural communities. When weather and other conditions were favourable, the modern varieties proved a success. However, in some areas complete crop failures were observed, whereas local varieties, with a higher variance of traits, were less susceptible to the frequent droughts. The loss of an entire crop was considered by the farming community as more than offset by the lower, average yields of the local variety that performed also under more extreme conditions.

According to the Convention on Biological Diversity (CBD), in some places there will be acceleration in the loss of the genetic and cultural diversity already occurring in agriculture as a result of global climate change. This loss will also be evident in crops and domestic animals. A $2.5^{\circ} \mathrm{C}$ rise in global temperature would determine major losses: between 20 and 30 per cent of all plant and animal species could face a high risk of extinction. Ecosystems and species display a wide range of vulnerabilities to climate change, depending on the imminence of exposure to ecosystem-specific critical thresholds. Local and rare breeds of livestock and plant species could be lost as a result of the impact of climate variability and disease epidemics. Biodiversity loss has global health implications and many of the anticipated health risks driven by climate variability will be attributable to a loss of genetic diversity (CBD, 2007).

\section{B. Mixed cropping}

When this strategy was analysed results showed that $56.5 \%$ of the respondents have used this as an indigenous coping strategy (Table 8). Note that the percent compares very closely with the percentage of those who have practiced diversification as an indigenous coping strateg. This may mean that those who practiced mixed cropping did so as they practiced diversification.

In modern science mixed cropping is also known as inter-cropping or co-cultivation. It is a type of agriculture that involves planting two or more types of crops simultaneously in the same field (Hirst, 2013). In general, the theory is that planting multiple crops at once will allow the crops to coexist either symbiotically or non-competitively together. Possible benefits of mixed cropping are to balance input and outgo of soil nutrients, to keep down weeds and insect pests, to resist climate extremes (wet, dry, hot, cold), to suppress plant diseases, to increase overall productivity and to use scarce resources to the fullest degree. While modern science refers to it as a theory, to the indigenous community in the study area, it is a practice.

\section{Increasing area under crops}

It was expected that the community used this option as a coping strategy. However, on analysis it was realized that though practiced, it was not a popular option as only $23 \%$ of the respondents considered it as coping strategy (Table 8). When more units of a good or a service are produced on a larger scale, yet with (on average) less input costs, economies of scale (ES) are said to be achieved (Heakal, 2009). This concept may be alternatively used to apply as a climate change coping strategy to mean that as an agro-pastoralist increases his production units he will have a better chance to decrease climate change risk impacts. The results therefore could mean that the community was wary of the higher risk of crop failure by increasing cropping area in light of the perceived decreasing rainfall. They therefore used this strategy reservedly as its benefits were in doubt.

\section{Traditional water harvesting for crop production}

Whether rain water harvesting was used as a coping strategy was investigated. The results after analysis showed that only $29.5 \%$ of the respondents used the strategy. This low practice could be linked to the findings on land ownership where most of the land, in the early years of focus of this study, was communally owned and therefore sustainability of water harvesting structures could not be guaranteed. Key informant interviews and focused group discussions revealed that the Jemps, (Ilchamus), community was known to have been practicing a form of bucket irrigation long before conventional irrigation was introduced in the area in the 1950s. However the community said during the dry season they could dig shallow well along the dry river beds 
and get water stored under the sand deposits. In depth probing into the communities' traditional water harvesting techniques revealed that they did not have any large scale methods of harvesting and storing water.

While ATPS (2013) observes that the potential of rain water harvesting in providing water supplementation to increase crop yield and reduce the risk of crop failure is very high, Critchley, (1984), a crop specialist with the BPSAAP project, states in his report about water harvesting that there is "no long history of water harvesting in Kenya" including Baringo.

\section{E. Short season cropping}

The growing season, which is the period of each year when crops can be grown, was expected to be an important coping strategy in order to take advantage of the decreasing rains when available. The study revealed that growing of short season crops was used by $64.9 \%$ of the respondents (Table 8). During the focused group discussions and key informant interviews millet, sorghum and maize were mentioned as the crops of choice used under this strategy. Further probing on maize seed used revealed that the type of seeds used were not the improved varieties but "traditional" varieties and similarly for the other crops. This could therefore be said to be a popular coping strategy.

Love, Noble and Parkinson(2009) says that the growing season is usually determined by climate and elevation, and in agriculture the crop selection. Location, temperature, daylight hours (photoperiod), and rainfall, may all be critical environmental factors. In hot climates, such as the study area, the growing season is limited by the availability of water, with little growth in the dry season. It is often possible to greatly extend the growing season in hot climates by irrigation. However it was expected that the option of taking advantage of the rainy season. A short season is considered to be anything below 110 days and any crop that matures within such a period is considered a short season crop. The Convention on Biological Diversity (2007) gives about 7,000 as the plant species that have been cultivated for food since agriculture began about 12,000 years ago. This number of species has been reducing overtime courtesy of plant breeding efforts and currently only about 15 species supply about $90 \%$ of human food. The crops referred to as traditional are among these remaining species. The term traditional varieties should therefore be understood to mean those varieties adopted since the colonial period but not hybrid/hibred (improved) varieties rather than varieties originating from the area.

\section{F. Indigenous crop protection}

Climate change may affect plant growth and production by promoting the spread of pests and diseases. A study by Bebber et al. (2013) demonstrates an average pole ward shift of $2.7 \pm 0.8 \mathrm{~km} \mathrm{yr}^{-1}$ since 1960 , in observations of hundreds of pests and pathogens. How the pest and pathogen impacts were indigenously coped with was investigated. Results revealed that $29.8 \%$ of the respondents used some form of indigenous crop protection strategy (Table 8 ).

The commonly mentioned indigenous methods included: dusting with soil and ash in the funnel of growing maize to control attacks by maize stalk borer; spraying animal urine on the crop-land where disease and pest occur; cutting and getting rid of infected plants; burning; use of resistant variety and placing poisonous plant leaves on harvested produce to control infestation by storage pests. For underground pests as moles, manual digging them out and use of traditional traps were used.

The percentage of practitioners at least explains existence of indigenous crop protection coping strategy. However the small percentage could mean that pest and pathogens were not a major threat to crop production. On the other hand other coping strategies could have contributed pest and pathogen control knowingly or not. For example, diversification and mixed cropping could be such strategies. A study by Njeru (2013) observes that pests have different food or oviposition preferences, and thus will only attack certain plant species or cultivars at specific growth stages. Concurrently, the host plant must produce certain attractants or portray characteristics that make them attractive and vulnerable to certain pests. Thus, crop and habitat diversification targeting to break this synergy could form an effective control mechanism for many pests that threaten crop production in the study area. Recent studies have reported successful control of stem borers on maize crop in Kenya, by employing crop mixtures in push-pull strategies, also referred to as stimulo-deterrent diversionary strategy, a technique so far adopted by more than 30,000 farmers across East Africa (Njeru, 2013). The same study also shows that using cultivar mixtures has been shown to control some plant diseases including maize leaf blight.

\section{G. Soil fertilization}

Soil fertility was expected to be a key factor in crop production. On analysis the results showed that $55 \%$ of the respondents used indigenous soil fertilization methods as a coping strategy to climate change (Table 8). This high percentage may explain that the strategy was popular and acceptable by the community. 
From the focused group discussions it came out that the agro-pastoralists perceive soil fertility in terms of the capacity of soils for long-term productivity, their permeability, water-holding capacity, drainage, tillage, manure requirement, and cultivability, soil colour, leaf colour and vigour of plant growth. They employ different indicators of knowing whether the soil is fertile or not. The major indicator mentioned by farmers is amount of crop yield. They believe that the use of indigenous soil fertility maintaining practices could bring about a sustainable solution to the problem of soil fertility. A variety of indigenous soil fertility management techniques practiced by agro-pastoralists in the study area include application of farmyard manure, mixed cropping, fallowing, and planting leguminous crops. The reasons given by the community on why they used the strategy concur with the scientific definition of soil fertility as the status of a soil with respect to its ability to supply elements essential for plant growth without a toxic concentration of any element to enhance productivity (Deenik, 2005).

\section{Correlations of indigenous crop-based coping strategies}

The items considered under these indigenous crop-based coping strategies includedcrop diversification, mixed cropping, planting short season crops, increasing area under crops, rainwater harvesting for crops, indigenous crop protection and indigenous soil fertilization. Significant relationships were found to exist, (Table 9), between:

a. Crop diversification and planting short season crops with a Pearson correlation $(r)=0.118,(p>0.05)$. This may be explained in that food security encompassed availability of food in terms of quantities and balance in nutrients provision to consumers among other factors. This therefore may be achieved through planting of different crop species such as cereals and pulses but with all having a common denominator of being short season crops in order for a harvest to be realized in the face of limited rainfall.

b. Planting short season crops and rainwater harvesting for crops with a Pearson correlation $(r)=0.123$, $(\mathrm{p}>0.05)$. This may be explained that planting of short season crops would take mean that the crops are likely to grow to maturity with the water availed under water harvesting. Since water harvesting is a technology that requires resources to implement, short season crops are expected to have a higher competitive advantage over long season crops in terms of water use economics.

c. Rainwater harvesting for crops and increasing area under crops with a Pearson correlation ( $\mathrm{r})=0.111$, $(\mathrm{p}>0.05)$. This may be explained that changing area share of crop pattern, is a useful tool for understanding the direction in which crop pattern changes are influenced by the variations in the comparative advantage of crops and crop groups in terms of water demand. Since water is a very important resource in crop production then its availability is expected to attract more land being put under crops.

Table 9: Correlations

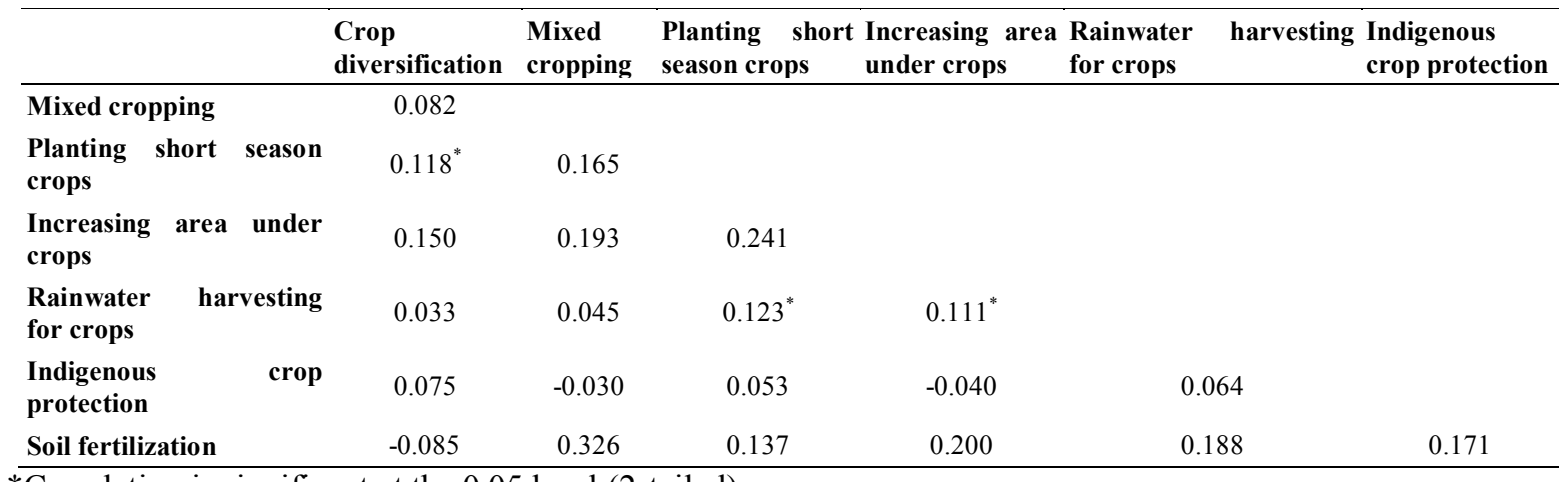

*Correlation is significant at the 0.05 level (2-tailed).

\section{Livestock and livelihoods}

\section{Indigenous Livestock-Based Livelihoods Coping Strategies}

In pastoral and agro-pastoral systems, livestock is a key asset for the people, fulfilling multiple economic, social and risk management functions. The impact of climate change is expected to heighten the vulnerability of livestock systems and reinforce existing factors that are affecting livestock production systems, such as rapid population and economic growth, rising demand for food (including livestock) and their products, conflict over scarce resources (land tenure, water, biofuels, etc.). For rural communities, losing livestock assets could trigger a collapse into chronic poverty and have a lasting effect on livelihoods. For example, during the drought that occurred in 1999-2001 in Kenya, it was estimated that over 2 million sheep and goats, 90,000 cattle and 14,000 camels died (Mutimba et al., 2010). This represented losses of 30\% of small stock and cattle and $18 \%$ of camel holding among the affected pastoralist populations (Aklilu and Wekesa, 2002). There was also a significant social impact: families separated, damaging the social networks that provide a safety net for 
pastoralists, and many moved to settlements and food distribution centres. Without sufficient livestock to provide for their food needs, many pastoralists became dependent on food aid. Once the drought ended, some could not return to the pastoralist sector because their livestock losses were too great and hence their livelihood had been destroyed (LEGS, 2009).

Livestock-based livelihood coping strategies can only be said to be sustainable only if they can allow resilience after climate change related stress and shocks, maintain or enhance their capabilities and assets, and provide sustainable livelihood opportunities for the next generation; and if they contribute net benefits to other livelihoods at the local and global levels, in the short and long term. This study took cognizance of the need to take into account how the affected communities traditionally coped with the climate change related stresses and shocks. The study investigated strategies related to livestock movement, feeding and herd adjustment. The results are as tabulated in Table 11.

\section{A. Livestock relocation}

On analysis, results showed that $70.5 \%$ of the community used this as coping strategy (Table 10). Different climate change related shocks can affect livestock's access to feed, for example in a drought, feed is expected to be in short supply due to lack of rainfall; while during floods feed resources may not be accessible and/or natural resources may have been lost. It was expected therefore that moving animals from such areas to areas where feed resources are accessible would be considered a viable option.

This revelation concurs with that of IIRR, Codraid and Acacia Consultants (2004) that the availability of water and pasture depends on the rain and pastoralists migrate to exploit these natural resources fully. In many pastoral societies, bringing together groups of livestock belonging to different owners and moving them to areas where resources are more abundant has long been practised in times of stress (Legs, 2009). The same document, however cautions that though this strategy may have benefits such as protecting the livestock from the vagaries of drought, it could also have associated risks such as inability to find adequate feed and water in the destination areas, expose the animals to infectious diseases, or lead to resource use conflicts. Also, the scope and possibility for relocation is becoming limited as the dry season grazing and drought reserve areas are gradually shrinking due to expansion of cropping in the wetter areas and because of restriction of movement of animals from one region to another as indicated by Tolera and Abebe (2007).

Table 10: Livestock Related Coping Strategies

\begin{tabular}{|c|c|c|c|c|c|}
\hline Coping Strategy & & Frequency & Valid Percent & Cumulative Percent & $\mathbf{N}$ \\
\hline \multirow[t]{2}{*}{ Relocation } & Yes & 261 & 70.5 & 70.5 & 370 \\
\hline & No & 109 & 29.5 & 100.0 & \\
\hline \multirow[t]{2}{*}{ Home feeding (in situ) } & Yes & 126 & 34.7 & 34.7 & 363 \\
\hline & No & 237 & 65.3 & 100.0 & \\
\hline \multirow[t]{2}{*}{ Herd adjustment by class } & Yes & 110 & 30.6 & 30.6 & 359 \\
\hline & No & 249 & 69.4 & 100.0 & \\
\hline \multirow[t]{2}{*}{ Herd adjustment by species } & Yes & 102 & 28.6 & 28.6 & 357 \\
\hline & No & 255 & 71.4 & 100.0 & \\
\hline \multirow[t]{2}{*}{ Livestock Diversification } & Yes & 86 & 24.4 & 24.4 & 352 \\
\hline & No & 266 & 75.6 & 100.0 & \\
\hline \multirow[t]{2}{*}{ Destocking } & Yes & 202 & 55.6 & 55.6 & 363 \\
\hline & No & 161 & 44.4 & 100.0 & \\
\hline \multirow[t]{2}{*}{ Pasture Conservation } & Yes & 105 & 29.5 & 29.5 & 356 \\
\hline & No & 251 & 70.5 & 100.0 & \\
\hline
\end{tabular}

Source: Author's Survey

However, relocation was not a strategy that individuals could undertake at will. Traditional mechanisms for relocation existed within the communities under study. During the focus group discussions it was disclosed that the local communities had ways of forecasting either drought or floods. They said that there were community members who could study the stars, animals intestines, wild animals behaviour and vegetation patterns, (flowering, shedding and mushrooming of leaves), to predict such occurrences and alert the community members to prepare for relocation. An example was given of theBalanitesaegyptiaca (Ngoswet in Kalenjin), tree that, if it produced fruits, then that spelt famine, that is, an indication of prolonged drought. The animals were moved using pre-agreed movement patterns. The discussants said that there were two types of movements. The first type being normal seasonal movements and the second type meant to allow people to escape or break away from the extraordinary conditions of the climatic events shocks such as prolonged drought and floods. In the study area, during the normal seasonal movements, it was disclosed that the agro-pastoralists moved their 
livestock from the lowland areas of the sub-county, (Kimalel, Marigat, Salaban, Ngambo, Ilchamus, Sandai, Kapkuikui, Loboi, Kimondis, Ilnga'arua and Ewalelsoi), during the dry periods to the higher areas of Mochongoi, Kimoriot, Arabal and Chebinyinyi and back. For the second type of movement, they moved longer distances sometimes to the bordering counties of Laikipia, Nyandarua, Nakuru and Mount Kenya. However, it was expressed that those animals that were taken to the mountain regions never came back as they died of adverse weather and diseases that they were not immune to. The few that survived were also sold off.

As climate variability becomes more variable, niches for different plant species alter. This may dictate change in future relocation patterns as change in plant species may modify animal diets and compromise the ability of smallholders to manage feed deficits; changes in the primary productivity of crops, forage and rangeland. Effects will depend significantly on location, system and species. With the study area being predominantly rangeland, pasture lands in the study area are vast but this should not be equated with abundance of forage. The marsh areas around swamps and lakes may provide important dry season grazing and may be of great importance in local livestock husbandry. Some of the water weeds such as ntorok (Tugen), from this swamp were used as food during drought.

The results however contradicted the view of the researcher that there could be loss of the opportunity for relocation due to the loss of quality and quantity of pastures which were observed to have been adversely affected by overgrazing. From key informant interviews, the overgrazing was attributed to the weakened traditional systems for delineating and preserving reserve grazing for times of drought and floods. Further loss of pasture lands to which the communities could have relocated to was attributed to cutting down of trees for charcoal burning, firewood, building materials and invasive species especially Prosopis juliflora, commonly known as "Mathenge". However, drought often affects large areas and so many people are affected at the same time (IIRR et al., 2004). For this reason, communities from far off localities presume availability of better pastures in what historically used to be dry season grazing areas, migrate there, just to find depleted pastures and exacerbate overgrazing and land degradation. For example, during the study data collection period, the Pokot community from East Pokot Sub-county had relocated to Marigat and the Jemps and Tugen communities were being pushed eastwards to Mochongoi and Kimoriot in a fierce resource based conflict. This observation supported IOM (2011) that under the natural, environmental and seasonality factors, climate pushes pastoralists and cattle rustlers to move seasonally. This behaviour, according to Homer-Dixon (1999) leads to increased conflicts presented as an indirect consequence of climate change.

These resultant conflicts have their consequences. For example, in the East African region, pastoralists living along the borders of Sudan, Kenya, Ethiopia, Tanzania and Uganda are losing their lives from increased cross-border resource-based armed conflicts. More specifically the Darful region of Sudan has suffered from chronic conflict due to recurrent drought for several years. Pastoralists and agro-pastoralists in the region derive up to $50 \%$ of their food/income from their livestock. However the conflict and drought have together caused significant livestock losses. Some villagers have over time reported losses of $70-100 \%$ due to livestock theft. Overcrowding of livestock and the disruption of veterinary services (both the result of insecurity) added to livestock mortality rates. The closure of the Sudan-Libya border used as conflict mitigation measure, also severely affected livestock trade and hence had a significant impact on livelihoods (LEGS, 2009). Thus the natural resource base has been depleted by the drought and conflict has restricted access to traditional migration routes as well as to large tracts of grazing lands.

It was also revealed that some community members, who could be associated with the remaining $29.5 \%$ (Table 10), had left livestock keeping and moved to towns as environmental migrants. Environmental migrants refers to people who are forced to migrate from or flee their home region due to sudden or long-term changes to their local environment which compromise their wellbeing or secure livelihood, such changes are held to include increased droughts; desertification; more intense and frequent storms; disruption of seasonal weather patterns and competition for scarce resources (Martin, 2013). In Kenya, a study carried in Nairobi by Njenga and Blanco (2009) revealed that $74 \%$ of environmental migrants migrated to Nairobi between 1991 and 2008 whereas $26 \%$ did so before 1990; consequently the number of migrants has increased in the last 20 years. In their study, Njenga and Blanco (2009) listed the main environmental reasons as lack of rainfall or drought and floods.

\section{B. Home feeding}

It was found that $34.7 \%$ used this strategy to cope (Table 10). This was explained that, during movement, the old, sick, women and young children were left behind. Some livestock and especially some lactating cows, sheep and goats were left behind and feed near homesteads as they provided milk to the remaining members of the family. Tolera and Abebe (2007) say the same about the Borana community of Moyale. However, the low percentage was attribute to the dire situation in terms of feed and water availability. It was explained that some trees and shrubs such as Acacia tortilis, Acacia nilotica, and Acacia brevispica; and other shrubs were preserved as an indigenous coping strategy to feed livestock during times of need. Some 
pastures/fodder was also conserved near homesteads for this purpose. As drought progress and grasses become depleted from the grazing land they lop the leaves and branches of the trees and feed to their animals. During very serious droughts for example, cactus leaves were said to be used to feed animals after burning them to remove thorns. A group in Loloro was said to have to the extent of establishing a cactus plot for fodder. The importance of these and other trees and shrubs is supported by Tolera and Abebe (2007), in their study of other pastoral and agro-pastoral communities.

Legs, (2009), is of the view that where livestock are likely to continue to make a significant contribution to households in an affected area, the benefits of home feeding simply for keeping animals alive are obvious. However, where livestock, particularly large ruminants are involved, and the climatic event is prolonged, they may require large quantities of feed which could exhaust reserves and call for sourcing and transportation of emergency feed over considerable distances. Such intervention therefore, in the face of becoming unsustainable should be implemented parallel with other strategies such as destocking or just target the most value affected livestock.

\section{Herd adjustment by class}

Table 10 shows that $30.6 \%$ of the respondents indicated that this strategy was used to cope with climatic events. Class referred to age and sex groups of various species of livestock. For example in cattle it referred to breeding cows, breeding bulls, bulling heifers, steers, yearling bulls, yearling heifers, weaners and calves. Herd adjustment by class involved reducing or increasing some classes of livestock based on their ability to survive through the climatic event. It was disclosed that communities controlled breeding of livestock when signs of drought appeared. This was done by either separating the breeding males from the breeding females or tying a skin apron in front of the breeding males' penis to avoid mating. The national institution mandated to carry out agricultural research in Kenya, Kenya Agricultural Research Institute (KARI), has adopted and improved on the breeding control apron, and recommends it as a scientific livestock breeding control equipment with the same objective of allowing breeding to coincide with times when feeds are available (Korir, 2008).

The community would go to the extent of killing calves and use the same as meat to avoid weakening their mothers through suckling or them themselves dying due to lack of milk. Increasing of breeding females was done when signs showed there might be good rains with resultant abundant pastures and water.

\section{Herd adjustment by species}

It was expected that agro-pastoralists would adjust their herds in terms of species to take advantage of a specific species capacity to utilize available resources. Species refer to types such as cattle, sheep or goats. Table 10 shows that $28.6 \%$ used this as a coping strategy. Though slightly lower the percentage compares well with the adjustment by class. This may be explained that each is not used exclusive of the other but are complementary. The slight difference in percentage could be attributed to that those adjusting by class already have the animals in the herd while some of those adjusting by species require selling one species to buy another as the climatic events dictate. PFE, IIRR and DF (2010) argue that pastoralists are changing their species composition from grazers (cattle and sheep), to browsers (camels and goats) to reduce risk and insure against natural as well as human-made shocks. They continue to argue that camels and goats easily adapt themselves to changes in pasture.

\section{E. Livestock diversification}

Investigation was carried out in order to establish whether the indigenous community traditionally used diversification as a coping strategy. On analysing this item, results showed that $24.4 \%$ of the respondents practiced this coping strategy (Table 11). The low percentage can be explained as a reflection of capacity to own and emergency preparedness. Livestock diversification is intended to give a wider choice in the livestock production system in a given area so as to expand production related activities on various livestock and also to lessen risk related to climate change.

Mandleni and Anim (2011) found that pastoralists diversify their livestock species to effectively utilize the scarce pasture and that herd diversification adaptation measure is possible through maintaining mixed herds which can withstand different climate and ecological conditions. Megersaet al., (2014), from their study underscored that livestock diversification was a major factor affecting households food security. Their study revealed that households practicing diversification had significantly fewer months of food deficit and a higher average offtake in the form of livestock sales than non-diversified ones. In Baringo bee keeping was also observed to be a major diversification option. 


\section{F. Destocking}

Reducing the number of livestock one owned was expected to be a strategy of choice in the face of imminent drought. On investigation, results revealed that $55.6 \% \mathrm{t}$ embraced destocking as a coping strategy (Table 10).

The respondents said that money earned through sale of livestock enabled them to buy food and also in purchase of new stock during recovery. They however said livestock marketing faces various challenges related to poor or lack of infrastructure, insecurity and prohibitive regulations. The need to dispose of large herds of livestock within a short period was cited as cause of very low prices as buyers took advantage of the producers' plight. This strategy has been used by government and other humanitarian agencies as an intervention during drought. The importance of this strategy was underscored by Abebeet al. (2008) by saying that destocking and other types of livestock-related drought assistance fit well with the concept of saving lives and livelihoods. When viewed from a livelihoods perspective, destocking is a way to exchange some animals for money, thereby giving pastoralists the financial resources they need to buy food, maintain a core herd, and access the services that they want to (rather than those that aid agencies provide).

\section{G. Pasture and fodder conservation}

Table 10 shows that $29.5 \%$ of the responded affirmed the use of pasture and fodder conservation as a coping strategy. The low percentage was attributed to the traditional communal land ownership system. This can be related to what IIRR et al. (2004) say about the Boran pastoralists of Southern Sudan. The community maintains emergency pasture reserves for critical times. These reserves are considered as a last resort. They are opened only if all other pasture options have been exhausted, and they are closed again when rain falls. Both the Boran and the Baringo communities have an elaborate system of fining people who graze their animals on these reserves without permission. Also the community fenced off an area of pasture land near their homesteads with cut thorny bushes or live thorny shrubs to allow for pasture preservation. They allow calves and sick animals to graze there in the dry season. Community members decide when to open this reserve pasture, when to close it again, and what types of animals can be grazed there. This tradition is common with agro-pastoral communities as Tolera and Abebe (2007) say of the communities living in Southern Ethiopia that they have a tradition of reserving or keeping aside a certain portion of the grassland for use as standing hay during the dry season. As with the Baringo communities, these portions are usually reserved for calves, lactating and weak animals

\section{H. Other coping strategies}

Two other coping strategies were revealed during focused discussions.

\section{Loaning of animals}

It was revealed that it was a common practice with the communities to loan some animals (specially breeding females), to friends and relatives as a risk reducing strategy. Families who lose animals during a drought or floods can go for some of the loaned animals or approach them for help in replenishing their herds.

\section{Herd splitting}

It was also revealed that some members of the community have two or more homes, mainly in the lowlands and the other in the highlands. They split their herds and distribute them in to the various homes.

\section{Disease control}

The discussants said that it had become clear with time that livestock diseases were increasing as climate changed. The communities took care to ensure that they do not lose animals through diseases through use of indigenous medicine and surgery. Most medicine was extracted from trees and shrubs.

\section{Correlations of indigenous livestock-based coping strategies}

The items considered under these indigenous livestock-based coping strategies included relocation, home feeding, herd adjustment by class, herd adjustment by species, destocking, species diversification destocking, and pasture/fodder conservation. Significant relationship was found to exist only between and home feeding, $(r)=0.136,(p>0.05)$ (Table 11). This meant that conserved pasture/fodder contributed a significant role to the welfare of the animals of the animals left behind and fed at home. While most items were positively correlated, meaning one contributed positively to the other and could be practiced concurrently, others such as relocation and home feeding were negatively correlated meaning they could only be practiced independent of each other. 


\section{Importance of indigenous coping strategies}

This study revealed that some of the strategies were applied for preparation for or mitigation against extreme climatic event shocks; others for survival during the events; while others were meant for recovery from the shocks. The study also revealed that in times of plenty the community used preservative strategies in readiness for times of dearth. During the climatic events the community used such strategies as herd adjustments, relocation, herd division and controlled breeding to ensure survival of the fewer animals and recovery after an event. This supports the recommendations in LEGS, (2009), on drought cycle management. Crop/livestock diversification was seen as one of the most ecologically feasible, cost-effective, and rational ways of reducing uncertainties in agro-pastoralism. This is in agreement with Lin (2011) who argues that diversification brings about higher spatial and temporal biodiversity on the farm and increases resilience.

Similar coping strategies used by Guyana and Suriname communities as documented by Bynoe (2012) include, shifting to other livelihoods less risky to climate change; adjusting cropping patterns; planting early maturing crops like cassava; practicing multi-cropping; relocating to higher ground; and asking God for help. In his work, Hogg (1987) argued that if development initiatives don't take into consideration local conditions and indigenous knowledge, they can lead to disastrous effects. In this work he further argues that desertification in both Turkana and Isiolo areas of Kenya has been largely caused by ill-conceived development that did not involve local communities from the beginning. He particularly mentions a phenomenon referred to as sedentarization which is a development effort that encouraged population and livestock concentration and in particular the growth of villages and towns. This development, he further argues, is a result of a government policy which emphasized settlement (in the interest of national security), and agriculture (to increase food production and combat desertification), rather than the local communities interests. He concludes that, any solution to the problems of the communities in these areas depends on a reversal of this policy to incorporate the local communities interests (Hogg, 1987).

Table 11: Correlations of livestock based coping strategies

\begin{tabular}{l|cccccc}
\hline & \multicolumn{7}{|c}{$\begin{array}{c}\text { Herd } \\
\text { Home }\end{array}$} & $\begin{array}{c}\text { Herd } \\
\text { adjustment }\end{array}$ & $\begin{array}{c}\text { Pasture and } \\
\text { adjustment } \\
\text { fodder } \\
\text { by species }\end{array}$ & Diversification Destocking & conservation \\
\hline Relocation & 1 & & & & & \\
$\begin{array}{l}\text { Home feeding } \\
\text { Herd adjustment by } \\
\text { class }\end{array}$ & -0.015 & 1 & & & & \\
$\begin{array}{l}\text { Herd adjustment by } \\
\text { species }\end{array}$ & 0.215 & -0.079 & 1 & & & \\
$\begin{array}{l}\text { Diversification } \\
\begin{array}{l}\text { Destocking } \\
\text { Pasture and fodder }\end{array}\end{array}$ & 0.150 & 0.163 & 0.326 & 1 & & \\
conservation & -0.052 & 0.080 & -0.146 & 0.152 & 1 & \\
\hline
\end{tabular}

*Correlation is significant at the 0.05 level (2 tailed)

\section{Conclusions and Recommendation}

\section{Indigenous coping and adaptation strategies}

The objective, sought to investigate whether there existed indigenous coping strategies to climate change. This study revealed existence of various indigenous strategies to either cope and/or adapt to climate change and had been used by communities resident in Baringo. We therefore conclude that:

i. There exists tremendous indigenous knowledge on how resident communities coped with climatic events.

ii. Indigenous strategies played an important role in achieving broader climate change adaptation goal. The goal of resilience after climatic events shocks.

\section{Recommendation:}

Stakeholders intending to formulate and implement climate change related adaptation strategies should take advantage of the existing knowledge base. The stake holders should involve the local community in the formulation and implementation processes of the intended interventions.

\section{Acknowledgement}

We acknowledge the Directorate of Graduate School and the Division of Research and Extension, Egerton University for providing funds to conduct this study. We also acknowledge the research assistants and 
respondents for their role in the course of conducting the study.Colleaguesand family members for their moral and financial support.

\section{References}

[1]. Abebe, D., Cullis, A., Catley, A., Aklilu, Y., Mekonnen, G. and Ghebrechirstos, Y. (2008).Impact of a commercial destocking relief intervention in Moyale district, southern Sudan. USA: Blackwell Publishing.

[2]. Aklilu, Y. and Wekesa, M. (2002).Drought, livestock and livelihoods: lessons from the 1999-2001 emergency response in the pastoral sector in Kenya. United Kingdom: Overseas Development Institute.

[3]. Anderson, S., Gundel, S. and Vanni, M. (2010).The impacts of climate change on food security in Africa: A synthesis of policy issues for Europe. IIED.

[4]. ATPS (2013).Indigenous rain water harvesting practices for climate adaptation and food security in dry areas: The case of Bahi district. ATPS Research Paper No. 22.

[5]. Benson, C. and Clay, E. J. (1998).The impact of drought on sub-Saharan economies. The World Bank Tech Paper No. 401, Washington, DC: World Bank.

[6]. Boko, M. I., Niang, A., Nyong, C., Vogel, A., Githeko, M., Medany, B., ...Yanda, P. (2007). Africaclimate change 2007: Impacts, adaptation and vulnerability. UK: Cambridge University Press.

[7]. Brooks, N. (1999). Dust-climate interactions in the Sahel-Sahara zone with particular reference to late $20^{\text {th }}$ century Sahel drought.University of East Anglia.

[8]. Bryan, E., Ringler, C., Okoba, B., Roncoli, C., Silvestri S., and Herrero, M. (2010).Coping with climate change and adapting to climate change in Kenya: Household and community strategies and determinants. The World Bank.

[9]. Bynoe, P. (2012). Indigenous perception of climate change, its impacts and coping strategies for sustainable livelihoods in Guyana and Suriname, France: Montpellier.

[10]. CBD (2007).Biodiversity and climate change, Secretariat of the Convention on Biological Diversity.

[11]. Critchly, W. R. S. (1984). Runoff harvesting for crop, range and tree production in the Baringo area. Kenya: BPSAAP, Marigat.

[12]. Elasha, B. O., Medany, M., Niang-Diop, I., Nyong, T., Tabo, R. and Vogel, V. (2006).Background paper on impacts, vulnerability and adaptation to climate change in Africa, Ghana: Accra.

[13]. Finucane, M. (2009). Why science alone won't solve the climate crisis: managing the climate risks in the Pacific. Asia Pacific Issues, 89:1-8.

[14]. GoK (2008). The National Livestock Policy: Sessional paper no.2 of 2008. Kenya: Ministry of Livestock Development.

[15]. GoK (2011).Agriculture Sector Development Support Programme: Programme Document. Kenya: Ministry of Agriculture.

[16]. GoK (2013).First County Integrated Development Plan 2013-2017. Kenya: County Government of Baringo.

[17]. Heakal, R. (2009). What are economies of scale? World Trade Organization.

[18]. Hirst, K. K. (2013). Agricultural technique known as mixed cropping. About.com. Accessed on 5/12/2013 at 7.35pm

[19]. Hogg, R. (1987). Development in Kenya: Drought, desertification and food security. African Affairs Vol. 86, No. 342 (Jan.1987), Pg. 47-58.

[20]. Homer-Dixon, T., (1999).Environment, Scarcity and Violence. New Jersey: Princeton University Press.

[21]. Homewood, K. and Lewis, J. (1987).Impact of drought on pastoral livestock in Baringo, Kenya 1983-85.Journal of Applied Ecology (1 987) 24, pp 615-631.

[22]. Hulme, M., Doherty, R., Ngara, T., New, M, and Lister, D. (2001). African climate change: 1900-2100. Climate Res17:145-168.

[23]. IIRR Codraid and Acacia Consultants. (2004). Drought cycle management: A toolkit for the drylands of the greater Horn of Africa. Nairobi: International Institute of Rural Reconstruction, The Hague: Cordaid, and Nairobi: Acacia Consultants.

[24]. IOM (2011). Migration for the benefit of all: An analysis of migration health in Kenya, Kenya: International Organization for Migration, Nairobi.

[25]. IPCC (2007).Climate change: The Fourth IPCC Assessment Report.Cambridge University Press.

[26]. Korir, B. K. (2008). Goat production in dry areas of Kenya. Nairobi: Kenya Agricultural Research Institute.

[27]. LEGS (2009).Livestock emergency guidelines and standards project handbook. India: Practical Action Publishing, Replika Press Pvt. Ltd.

[28]. Lin, B. B. (2011). Resilience in agriculture through crop diversification: Adaptive management for environmental change. BioScience, 61, 183-193.

[29]. Love, S. L., Noble, K. and Parkinson, S. (2009). Introduction to short-season gardening in Idaho.University of Idaho.

[30]. Makenzi, P. M. (2004). Indigenous knowledge in natural resources management: A case of forest biodiversity conservation in Baringo District, Kenya. Moi University.

[31]. Mandleni, B. and Anim, F. (2011).Perceptions of cattle and sheep farmers on climate change and adaptation in the Eastern Cape province of South Africa. J. Hum. Ecol., 34: 107-112.

[32]. Martin, S. F. (2013). Environmental change and migration: What we know. Washington, DC: Migration Policy Institute.

[33]. Megersa, B., Markemann, A., Angassa, A. and Zarate, A. V. (2014).The role of livestock diversification in ensuring household food security under a changing climate in Borana, Ethiopia. Food Security February 2014 Volume 6, Issue 1:15-58.

[34]. Mutimba, S., Mayieko, S., Olum, P. and Wanyama, K. (2010).Climate change vulnerability and adaptation preparedness in Kenya. Heinrich BöllStiftung, East and Horn of Africa.

[35]. Naessens, J. (2006). Bovine trypanotolerance: A natural ability to prevent severe anaemia and haemophagocytic syndrome? Int J Parasitol. 2006 May 1, 36(5):521-8.

[36]. Nakashima, D. J., Galloway, M K., Thulstrup, H. D., Ramos Castillo, A. and Rubis, J. T., (2012). Weathering uncertainty: Traditional knowledge for climate change assessment and adaptation. Paris: UNESCO and Darwin: United Nations University.

[37]. NEMA (2009).National Environment Action Plan, 2009-2013. Kenya: Ministry Of Environment and Mineral Resources.

[38]. Ngaira, J. K. (2006). Implications of climate change on the management of Rift Valley lakes in Kenya, The case of Lake Baringo. Kenya: School of Environment and Earth Sciences, Maseno University.

[39]. Ngugi, R. K. and Nyariki, D. M. (2005). Rural livelihoods in the arid and semi-arid environments of Kenya: Sustainable alternatives and challenges. Agriculture and Human Values 22: $65-71$.

[40]. Njeru, E. M. (2013). Crop diversification: A potential strategy to mitigate food insecurity by smallholders in sub-Saharan Africa. Journal of Agriculture, Food Systems, and Community Development, ISSN: 2152-0801.

[41]. Nyariki, D. M., Wiggins, S. and Imungi, J. K. (2002). Levels and causes of household food and nutrition insecurity in dryland Kenya.Ecology Journal of Food and Nutrition 41:155-176. 
[42]. Nyong, A., Adesina, F. and Elasha, B. O. (2007). The value of indigenous knowledge in climate change mitigation and adaptation strategies in the African Sahel. Mitig Adapt Strat Glob Change (2007) 12:787-797, Springer Science.

[43]. Ojwang, G. O., Agatsiva, J. and Situma, C. (2010).Analysis of climate change and vulnerability risks in the smallholder sector: Case studies of the Laikipia and Narok Districts representing major agro-ecological zones in Kenya. United Nations, Rome: Department of Resource Surveys and Remote Sensing (DRSRS).

[44]. Olago, D. O., Opere, A. and Barongo, J. (2009). Holocene palaeohydrology, Groundwater and climate change in the Lake Basin of central Kenya, Hydrological science Journal. Kenya: University of Nairobi.

[45]. Ouma, R. Mude, A and Van De Steeg, J. (2011).Dealing with climate related risks: Some pioneering ideas for enhanced pastoral risk management in Africa. Expl Agric. (2011), Volume 47 (2):375-393. Cambridge University Press.

[46]. Raleigh, C., Jordan L. and Salehyan I. (2008).Assessing the impact of climate change on migration and conflict. Washington, DC: The World Bank.

[47]. Raygorodetsky, G. (2011). Why traditional knowledge holds the key to climate change, climate variability, culture \& religions. Japan: United Nations University.

[48]. Rowlinson, P. (2008). Adapting livestock production systems to climate change: Temperate zones.Tunisia: Livestock and Global Change conference proceeding.

[49]. Steinfeld, H. and Maki-Hokkonen, J. (1997).A classification of livestock production. World Animal Review v.84/85:83-94.

[50]. Tari, D. A. (2000).Pastoralism and climate change debate. Oxford, UK.

[51]. The World Bank.(2012). India data.India: World Bank.

[52]. The World Bank. (2013). Regions: Sub-Sahara Africa. The World Bank Group.

[53]. Tolera, A. and Abebe, A. (2007).Livestock production in pastoral and agro-pastoral production system of southern Ethiopia.Livestock Research for Rural Development 2007, Volume 19,Number 12.

[54]. Trench, P., Rowley, J., Diarra, M., Sano, F. and Keita B. (2007).Beyond any drought - Root causes of chronic vulnerability in the Sahel.The Sahel Working Group.

[55]. UN (2006).Kenya national development report. UN: World Water Assessment Programme.

[56]. Worden, J., Western, D. and Waruingi, L. (2009).Exploring potential economic and livelihood impacts of climate change and possible adaptation mechanisms in the Kenyan rangelands.African Conservation Centre.

[57]. Yazan, A. M. E., Nyariki, D. M., Wasonga, V. O. and Ekaya, W. N. (2012). Transient poverty among pastoral households in the semi-arid lowland of Baringo District, Kenya, Ozean Journal of Social Sciences 5(1), 2012, Ozean Publication. 